\title{
Lidt gammelt nyt om bibliotekets berømte inkahåndskrift
}

Af seniorforsker, cand. mag. Harald Ilsøe

På Det kongelige Biblioteks udstilling i efteråret 1992 To verdener mødtes var udstillingens ubestridte klenodie håndskriftet med Felipe Guaman Poma Ayalas gennemillustrerede skildring af Andes-områdets historie og erobring af spanierne. Den kendes kun i dette ene eksemplar, der er skrevet på spansk af forfatteren ca. 1615 og stilet til Kong Filip III af Spanien. Niels Foch fremhævede dens betydning i åbningstalen (seovenfor s.23-27), og i Fund og Forskning har Rolena Adorno givet en udmærket introduktion til forståelse af forfatteren og hans håndskrift med udførlig bibliografi (årg. XXIV, 1979-80, s. 7-28).

Set fra en overleverings- og bibliotekshistorisk synsvinkel er og bliver det en gåde, hvordan håndskriftet er havnet i Danmark. Efter at Ayala har afsluttet det, er dets opholdssted ukendt indtil ca. 1785, da der blev holdt mønstring over bestanden af håndskrifter, som siden Frederik IIIs dage var indlemmet i Det kongelige Bibliotek. De fik tildelt signaturbetegnelsen „Gl. kgl. Samling " med tilføjelse af formatangivelse og individuelt pladsnummer, og inkahåndskriftet fik ved den lejlighed sin stadig gældende signatur Gl. kgl. Saml. 2332 4to. Alle forsøg på at udpege en forbindelse til danskere, der har været i Spanien inden da, er strandet på, at håndskriftet tilsyneladende ikke figurerer i nogen af de relevante biblioteks-eller bogauktionskataloger. Det vil sige: figurerer ikke på genkendelig måde, for katalogerne er ikke sjældent så skødesløst og uklart affattede, at identificering af bestemte håndskrifter ofte er umulig. Adorno har f.eks. forgæves gennemgået auktionskatalogen fra 1682 over den danske diplomat Cornelius Lerches bibliotek, der notorisk rummede bøger og manuskripter erhvervet i Spanien. Men dertil må føjes den omstændighed, at rester fra Lerches bibliotek, som muligvis har været holdt 
tilbage fra auktionen, senere dukkede op i embedsmanden W.A. von Ostens besiddelse. Gennemgås følgelig auktionskatalogerne over hans store bibliotek 1750-64, finder man da også her et par spanske håndskrifter, men de er helt utilstrækkeligt registreret. Ærgerligt nok, for et auktionsnummer, som er opført under manuskripter i kvartformat og blot kaldes „Et Spansk Manuskript" , kunne jo have indeholdt inkahåndskriftet. Noget holdepunkt giver den summariske betegnelse selvsagt ikke, og det må nok i det hele anses for tvivlsomt, om gåden kan løses ad bibliotekskatalogernes vej.

Skønt Ayalas håndskrift har været behørigt registreret i bibliotekets håndskriftkatalog siden omkring 1785, skal det først være „opdaget”, dvs. omtalt i forskningssammenhæng, i året 1908, da en tysk forsker beskrev det på tryk (Adorno s. 19ff). Det er i denne forbindelse der kan meddeles et par oplysninger, som hidtil har været overset. Håndskriftet har nemlig ikke som antaget ligget ubemærket hen. Allerede Det kongelige Biblioteks formidable overbibliotekar 1788-1823, den meget vidende og spanskkyndige D.G. Moldenhawer, har været ganske klar over dets usædvanlige indhold. 1802opholdt den tyske embedsmand og oplysningsforfatter August Hennings sig i København og besøgte biblioteket, hvor han fik sig en længere snak med Moldenhawer. I samtalens løb kom de ind på bibliotekets rigdom på spansksproget litteratur, og i sin dagbog refererer Hennings ham under 11. sept. for at have fortalt følgende: „Die königl. Bibliothek hat einen reichen Vorrath Spanischer Schriften, die aus dem angekauften Nachlasse eines in Copenhagen verstorbenen spanischen Gesandten herrühren, der ein gelehrter Mann war ... Unter dem angekauften Vorrathe ist eine sehr merkwürdige Handschrift eines peruanischen Inka, der in seinem 40 Jahre getauft wurde, und den Namen Ajala erhielt. Sie enthält die Geschichte der Sitten und Begebenheiten in Peru vor der spanischen Eroberung. Moldenhawer arbeitet an einer Übersetzung" (Danske Magazin 7. rk. I, 1934, s. 148).

Det er en ganske præcis omtale af inkahåndskriftet, og to af Moldenhawers meddelelser har her en vis interesse. For det første at Moldenhawer mente at vide, at det var købt sammen med efterladenskaber, som havde tilhørt „en i København afdød spansk gesandt, der var en lærd mand". Kombinationen ",gesandt" og „lærd mand“ passer desværre ikke videre godt på de personer, der indtil nu har været taget i betragtning, Cornelius Lerche og adelsmanden Jørgen Reedtz (d. 1680), for selv om de havde været i Spanien 


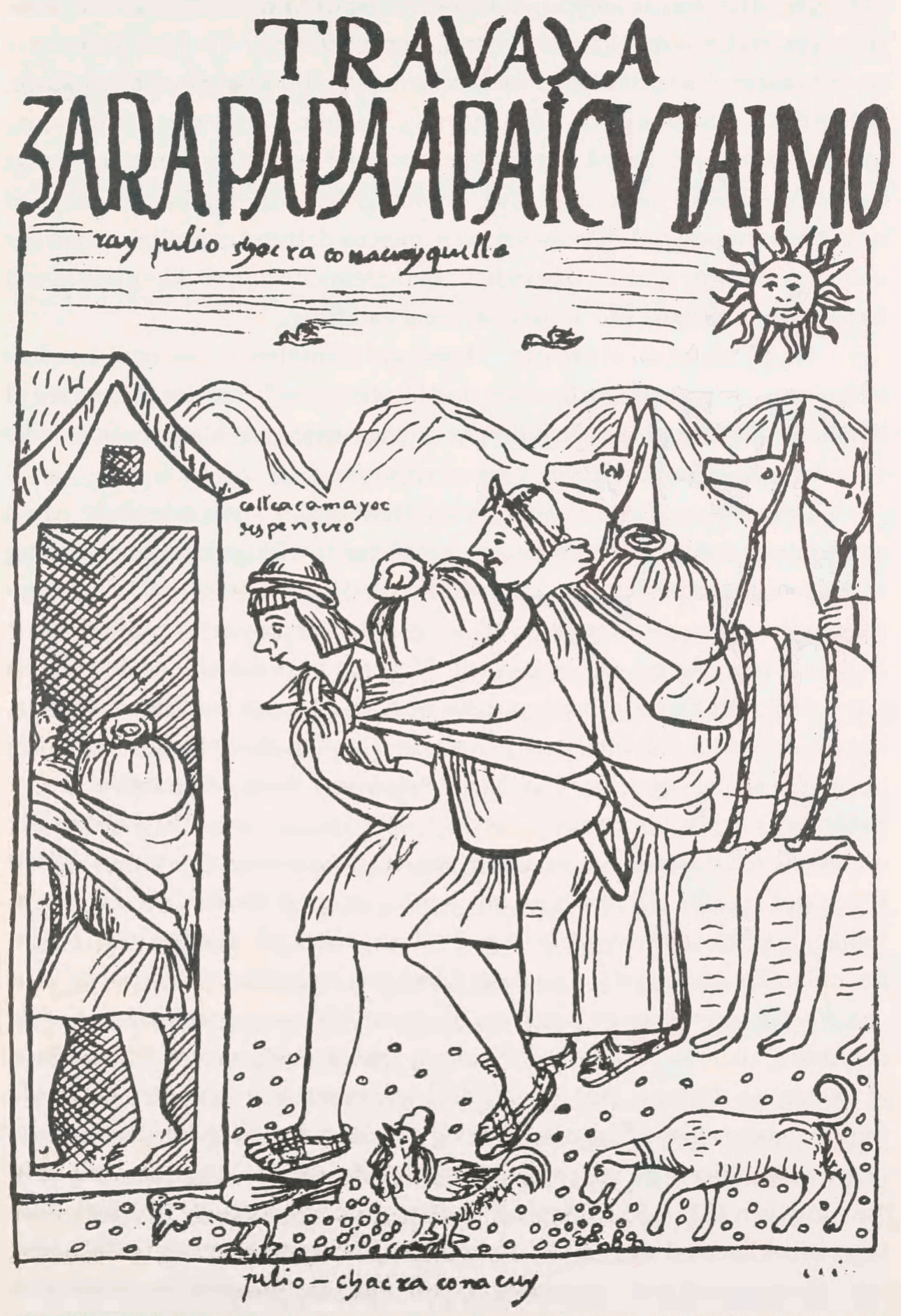


som gesandter, kan de næppe kaldes lærde. Og den synes heller ikke at passe på nogen anden, som biblioteket har fået spanske bøger fra. Faktisk skyldtes hovedmassen af spanske bøger før Moldenhawers tid de tre privatbiblioteker, Frederik III erhvervede ca. 1660, navnlig Joachim Gersdorffs bibliotek, og ingen af disses ejere har på noget tidspunkt været gesandter i Spanien. Muligt har Moldenhawer derfor taget fejl, og muligt har han blot i almindelighed udtalt en formodning om proveniensen, men da det også er muligt, at han har været $\mathrm{i}$ besiddelse af en nu tabt viden, bør dette spor trods alt ikke overses ved fremtidige undersøgelser af håndskriftets vandring.

Noget andet er, at ordene i Hennings' formulering vist også kan fortolkes som „en gesandt fra Spanien død i København“ - om det så kan føre til noget. De eksisterende fremstillinger af bogsamlingens historie synes ikke at give støtte til en fortolkning i denne retning.

Dernæst meddelte Moldenhawer Hennings, at han arbejdede på en oversættelse af Ayalas beretning. Hvor er så den? Da en grundig gennemgang af Moldenhawers papirer ikke har bragt den for dagen (Ada Adler:D.G.Moldenhawer og hans Haandskriftsamling, 1917), og da Moldenhawer havde for vane at lufte litterære planer, som han aldrig fik bragt til udførelse, er det et stort spørgsmål, om han overhovedet kom ordentlig i gang med oversættelsen. Men glemt var håndskriftet ikke. Planen blev luftet endnu engang, da han 1810 opstillede en liste over håndskrifter $\mathrm{i}$ biblioteket, der burde publiceres eller behandles på tryk. Listen var opdelt i tre kategorier, og under kategorien, der omhandlede kilder til de europæiske staters historie, stod som punkt 5 af ialt 6 punkter nævnt: „Efterretning om og Prøver af en Krønike af Peru, som indbefatter Ynkaernes og dette Riges Erobrings Historie, med en ved Tegninger oplyst Beskrivelse om dets indre Mærkværdigheder".

Altså atter Ayalas inkakrønike. Forsåvidt var håndskriftet og dets betydning allerede „opdaget“ i Danmark af Moldenhawer ved begyndelsen af 1800-tallet. På den anden side må det konstateres, at E.C. Werlauff citerede Moldenhawers liste i begge udgaver af sin skildring af bibliotekets historie uden at identificere planens punkt 5 med håndskriftet i Gl. kgl. Samling 2232 4to (udgaven 1825 s. 352; 1844 s. 333). Som det ofte går havde Moldenhawer taget sin viden med sig i graven, og håndskriftet var nu glemt. Først $1908 \mathrm{blev}$ det - ikke opdaget, men - genopdaget, og denne gang præsenteret på tryk som det enestående håndskrift, det er. 